\title{
Pengaruh Lingkungan Kerja Terhadap Kepuasan Kerja Pegawai Pada Pusat Pendidikan Dan Pelatihan (Pusdiklat) Perdagangan Depok
}

\author{
Faisal Romdonih \\ Dosen Falkutas Ekonomi, Universitas Pamulang \\ Email : dosen01174@unpam.ac.id
}

\begin{abstract}
ABSTRAK
Tujuan dari penelitian ini adalah untuk mengetahui lingkungan kerja PUSDIKLAT Perdagangan, mengetahui kepuasan kerja pegawai PUSDIKLAT Perdagangan, dan mengetahui pengaruh lingkungan kerja terhadap kepuasan kerja pegawai PUSDIKLAT Perdagangan.

Metode penelitian yang digunakan dalam penelitian ini adalah penelitian kuantitatif. Metode pengumpulan data dalam penelitian ini dengan menggunakan teknik angket/kuesioner. Teknik sampling yang digunakan adalah sampel jenuh yaitu sebanyak 76 pegawai. Analisis data yang digunakan adalah statisik deskriptif, uji validitas, uji reliabilitas, uji koefisien korelasi, uji regresi linier sederhana, uji koefisien determinasi, dan uji signifikansi (uji-t).

Berdasarkan hasil penelitian yang telah dilakukan menghasilkan nilai koefisien korelasi sebesar $\mathrm{r}=0,678$ yang berarti korelasi antara lingkungan kerja dengan kepuasan kerja pegawai berada pada kategori kuat. Persamaan regresi linier sederhana yang telah ditemukan adalah $Y=6,454+0,730 x$, artinya nilai konstanta $\mathrm{a}=6,454$ berpengaruh positif terhadap perubahan lingkungan kerja $(\mathrm{X})$, sedangkan nilai $b=0,730$ artinya variabel kepuasan kerja $(Y)$ akan bertambah 0,730 dari setiap perubahan variabel $\mathrm{X}$. Koefisien determinasi (KD) diperoleh nilai sebesar 45,96\% dan sisanya sebesar 54,04\% dipengaruhi beberapa faktor lain yang tidak diteliti oleh peneliti. Berdasarkan hasil uji-t yang telah dilakukan maka $\mathrm{t}_{\text {hitung }}>\mathrm{t}_{\text {tabel }}=7,934>1,992$ yang artinya bahwa Ho ditolak dan Ha diterima, artinya lingkungan kerja (X) mempunyai pengaruh yang signifikan terhadap kepuasan kerja pegawai (Y) pada Pusat Pendidikan dan Pelatihan (PUSDIKLAT) Perdagangan Depok.
\end{abstract}

\section{Kata Kunci :Lingkungan Kerja, Kepuasan Kerja, PUSDIKLAT Perdagangan}




\section{PENDAHULUAN}

\section{LATAR BELAKANG MASALAH}

Dalam sebuah instansi atau organisasi khususnya pada instansi pemerintahan pegawai merupakanaset yang sangat penting karena tanpa adanya pegawaiinstansi atauorganisasi akan sulit untuk mencapai tujuannya. Kemampuan dari seorangindividu dalam melakukan pekerjaannya tergantung dari apa yang telahmereka kerjakan dan mereka dapatkan. Untuk mendapatkan hasil yangterbaik tentunya juga diperlukan adanya sumber daya manusia yangberkualitas.

Faktoryang mempengaruhi keberhasilan suatu instansi pun salah satunya adalah pegawai, karena berkaitan langsung dengankegiatan instansi. Dalam hal ini pegawai diharapkan dapatmemberikan hasil yang maksimal sehingga tujuan dari instansi atauorganisasi dapat tercapai. Kepuasan kerja merupakan salah satu faktor bagi pegawai agar dapat bekerja secara maksimal. Kepuasan kerja seorang pegawai juga merupakankunci dari sehatnya sebuah instansi.

Kepuasaan kerja merupakan perasaan senang atau tidak senang pekerja dalam memandang pekerjaanya.Apabila seseorang senang terhadap pekerjaanya, maka orang tersebut puas terhadap pekerjaanya.Semakin banyak aspekaspek dalam pekerjaan yang sesuai dengan keinginan individu tersebut, maka semakin tinggi tingkat kepuasaan yang dirasakanya, sebaliknya semakinsedikit aspekaspek dalam pekerjaan yang sesuai dengan keinginan individu, maka semakin rendah tingkat kepuasaan yang dirasakanya.

Peningkatan kepuasan kerja dapat dilakukan dengan menciptakan lingkungan kerja yang baik dan nyaman, baik lingkungan kerja fisik maupun non-fisik. Kondisi demikian akan mampu membuat pegawai merasa senang, nyaman, dan betah didalam suatu instansi atau organisasi. Lingkungan kerja fisik yang baik dapat mengurangi tingkat kejenuhan dan tingkat stres pegawai. Sehingga prestasi pegawai akan meningkat. Fasilitas kerja yang baik tanpa didukung oleh lingkungan kerja yang bagus tidak akan ada artinya. Lingkungan kerja baik fisik maupun non-fisik berperan penting untuk menciptakan dan meningkatkan kepuasan kerja para pegawai. Pegawai yang puas akan lebih loyal terhadap instansi, sehingga dengan demikian pegawai dapat melaksanakan tugas dan tanggung jawabnya dengan baik.

Objek penelitian yang akan penulis teliti adalah Pusat Pendidikan dan Pelatihan

(PUSDIKLAT)Perdagangan yang merupakan unit Eselon II di lingkungan sekretariat jenderal Kementerian Perdagangan yang berkompeten melaksanakan peningkatan dan pengembangan sumber daya manusia sektor perdagangan. Pusat Pendidikan dan Pelatihan (PUSDIKLAT)

Perdagangan memiliki konsep dasar pembangunan sumber daya manusia yang mengacu pada 4 (empat) pilar sumber daya manusia berbasis kompetensi yaitu mewujudkan sumber daya manusia yang memiliki pengetahuan (Learning to know), memiliki keahlian (Learning to do), 
mampu bersikap profesional (Learning to be), mampu bersosialisasi dan berkomunikasi dengan lingkungannya (Learning to live together).

Berdasarkan dengan masalah diatas maka penulis tertarik untuk melakukan penelitian pada PUSDIKLAT Perdagangan Depok dengan judul : "Pengaruh Lingkungan Kerja Terhadap Kepuasan Kerja Pegawai Pada Pusat Pendidikan dan Pelatihan (PUSDIKLAT) Perdagangan Depok"

PEMBATASAN MASALAH

Berdasarkan uraian dari latar belakang dan identifikasi masalah di atas, maka penyusunan skripsi ini dibatasi dalam pembahasannya. Hal tersebut di lakukan agar tidak melebar ke arah yang berbeda-beda, maka penulis hanya membatasi pada variabel lingkungan kerja dan kepuasan kerja.

1. Yang dimaksud lingkungan kerja dalam skripsi ini adalah segala sesuatu yang adadi sekitar para pekerja yang dapat mempengaruhi dirinya dalammenjelankan tugastugas yang diembannya.

2. Yang dimaksud kepuasan kerja dalam penelitian ini adalah derajat positif atau negatifnya seseorang mengenai berbagai segi tugastugas pekerjaan, tempat kerja dan hubungan dengan sesama pekerja atau perasaan senang maupun tidak senang karyawan terhadap pekerjaannya.

3. Penelitian ini dilakukan di Pusat Pendidikan Dan Pelatihan (PUSDIKLAT) Perdagangan di Jl. Abdul Wahab Raya No. 8, Sawangan, Kota Depok.

\section{TUJUAN PENELITIAN}

1. Tujuan Penelitian

a. Untuk mengetahui lingkungan kerja pada PUSDIKLAT Perdagangan.

b. Untuk mengetahui kepuasan kerja pegawai pada PUSDIKLAT Perdagangan.

c. Untuk mengetahui pengaruh lingkungan kerja terhadap kepuasan kerja pada PUSDIKLAT Perdagangan.

\section{TINJAUAN TEORITIK}

\section{Pengertian Lingkungan Kerja}

a. Menurut Sedarmayati (2011: 2)

Lingkungan kerja adalah keseluruhan alat perkakas dan bahan yang dihadapi, lingkungan sekitarnya di mana seseorang bekerja, metode kerjanya, serta pengaturan kerjanya baik sebagai perseorangan maupun sebagai kelompok.

b. Menurut Herman Sofyandi (2008: 38)

Mendefinisikan lingkungan kerja sebagai serangkaian faktor yang mempengaruhi kinerja dari fungsifungsi atau aktivitas-aktivitas manajemen sumber daya manusia yang terdiri dari faktor-faktor internal yang bersumber dari dalam organisasi.

\section{Jenis Lingkungan Kerja}

Menurut Sedarmayanti (2009: 21) secara garis besar, jenis lingkungan kerja terbagi menjadi 2 yakni lingkungan kerja fisik, dan lingkungan kerja non fisik.

\section{Kepuasan Kerja}

a.Menurut Suwano dalam Suparno (2015: 169) Kepuasan kerja adalah merupakan suatu kondisi psikologis yang menyenangkan atas perasaan karyawan yang 
sangat subjektif dan sangat tergantung pada individu yang bersangkutan dengan lingkungan kerjanya, dan kepuasan kerja merupakan suatu konsep multificated (banyak dimensi) ia dapat memakai sikap secara

b.menyeluruh atau mengacu pada bagian pekerjaan seseorang.

c. Menurut Hasibuan (2014: 202) Kepuasan kerja adalah sikap emosional yang menyenangkan dan mencintai pekerjaannya. Sikap ini dicerminkan oleh moral kerja, kedisiplinan, dan prestasi kerja.

\section{HIPOTESIS PENELITIAN}

Menurut Sugiyono (2015: 64) hipotesis merupakan jawaban sementara terhadap rumusan masalah penelitian, di mana rumusan masalah penelitian telah dinyatakan dalam bentuk kalimat pertanyaan. Dikatakan sementara, karena jawaban yang diberikan baru didasarkan pada teori yang relevan, belum didasarkan pada fakta-fakta empiris yang di peroleh melalui pengumpulan data. Jadi hipotesis juga dapat dinyatakan sebagai jawaban teoritis terhadap rumusan masalah penelitian, belum jawaban yang empirik. Dalam penelitian hipotesisnya yaitu:

Ho = Tidak terdapat pengaruh yang signifikan antara lingkungan kerja terhadap kepuasan kerja pegawai pada PUSDIKLAT Perdagangan.

$\mathrm{Ha}=$ Terdapat Pengaruh yang signifikan antara lingkungan kerja terhadap

kepuasan kerja pegawai pada PUSDIKLAT Perdagangan.

\section{METODOLOGI PENELITIAN TEMPAT DAN WAKTUPENELITIAN}

Tempat Peneltian dilakukan pada PUSDIKLAT Perdagangan yang bertempat di Jl. Abdul Wahab Raya No.8, Kedaung, Sawangan, Kota Depok, Jawa Barat 16516, Indonesia.Waktu penelitian yang diberikan perusahaan untuk melakukan penelitian adalah selama bulan Agustus sampai dengan bulan september 2017.

\section{POPULASI DAN SAMPEL}

Adapun populasi dalam penelitian ini adalah .PUSDIKLAT Perdagangan

Teknik yang digunakan
dalam penarikan
menggunakan teknik
sampling (convenience
Sampental
Sampling).
yang secara kebetulan bekerja di
PUSDIKLAT.

\section{VARIABEL PENELITIAN}

Dalam penelitian ini terdapat dua variabel, yaitu variabel independen dan variabel dependen, seperti berikut :

1. Variabel bebas (independent variable) Variabel bebas yang dalam hubungannya dengan variabel lain bertindak sebagai penyebab atau yang mempengaruhi variabel dependen. Padapenelitian ini sebagai variabel independen yakni harga, promosi dan store atmosfer. Variabel independen sering disebut sebagai predictor yang dilambangkan dengan $\mathrm{X}$.

2. Variabel terikat (dependent variable) Variabel yang tergantung dengan variabel lain, 
atau variabel yang dapat dipengaruhi oleh variabel lain. Sering disebut variabel respon di mana dalam penelitian ini adalah keputusan konsumen untuk berbelanja yang dilambangkan dengan Y.

\section{DEFINISI}

OPERASIONAL

\section{VARIABEL}

Pengertian operasional variabel ini kemudian diuraikan menjadi indikator empiris yang meliputi :

Beberapa variabel yang digunakan dalam penelitian ini adalah berupa variabel independen dan variabel dependen. Variabel independen atau variabel bebas yang tidak berubah atau berdiri sendiri yaitu berupa lingkungan kerja yang mempengaruhi variabel dependen atau terikat yaitu berupa kepuasan kerja karyawan pada Pusat Pendidikan dan Pelatihan (PUSDIKLAT) Perdagangan.

\section{Variabel X (Lingkungan Kerja)}

$$
\text { Sedarmayanti (2011: }
$$

menyatakan bahwa lingkungan kerja adalah keseluruhan alat perkakas dan bahan yang dihadapi lingkungan kerja sekitarnya dimana seseorang bekerja, metode kerjanya serta pengaturan kerjanya serta pengaturan kerjanya baik sebagai perorangan maupun sebagai kelompok.

$$
\text { Sedarmayanti (2009: 21) }
$$

menjelaskan Indikator dari lingkungan kerja adalah sebagai berikut:
a. Penerangan/Cahaya di tempat kerja

Cahaya atau penerangan sangat besar manfaatnya bagi karyawan guna mendapat keselamatan dan kelancaran kerja, oleh sebab itu perlu diperhatikan adanya penerangan (cahaya) yang terang tetapi tidak menyilaukan.

b.Temperatur/suhu udara di tempat kerja

Dalam keadaan normal, tiap anggota tubuh manusia mempunyai temperatur yang berbeda.

c. Kebisingan di tempat kerja

Salah satu polusi yang cukup menyibukkan para pakar untuk mengatasinya adalah kebisingan, yaitu bunyi yang tidak dikehendaki oleh telinga.

d. Bau-bauan di tempat kerja

Adanya bau-bauan di sekitar tempat kerja dapat dianggap sebagai pencemaran, karena dapat mengganggu konsentrasi bekerja.

e. Tata warna di tempat kerja

Menata warna di tempat kerja perlu dipelajari dan direncanakan dengan sebaik-baiknya.

f. Dekorasi di tempat kerja

Dekorasi ada hubungannya dengan tata warna yang baik. Karena itu dekorasi tidak hanya berkaitan dengan hiasan ruang kerja saja tetapi berkaitan juga dengan cara mengatur tata letak, tata warna, perlengkapan dan lainnya untuk bekerja.

g.Keamanan di tempat kerja

Guna menjaga tempat dan kondisi lingkungan kerja tetap dalam keadaan aman maka perlu diperhatikan adanya keberadaannya. 2.Variabel Y (Kepuasan Kerja)

Menurut Handoko (2014: 197) kepuasan kerja adalah keadaan emosional yang menyenangkan atau tidak menyenangkan dengan mana para karyawan memandang pekerjaan mereka. Indikatorindikator kepuasan kerja adalah:

a.Tingkat perputaran karyawan 
Kepuasan kerja yang lebih rendah biasanya akan mengakibatkan perputaran karyawan lebih tinggi. Mereka lebih mudah meninggalkan perusahaan dan mencari kesempatan di perusahaan lain

b. Tingkat absensi karyawan

Para karyawan yang kurang mendapatkan kepuasan kerja cenderung lebih sering absen.

c.Umur karyawan

Semakin tua umur karyawan, mereka cenderung lebih terpuaskan dengan pekerjaan-pekerjaan mereka. Para karyawan yang lebih muda cenderung kurang terpuaskan, karena berbagai pengharapan yang lebih tinggi, kurang penyesuaian, dan penyebab-penyebab lainnya.

d.Jenjang pekerjaan

Orang-orang dengan jenjang pekerjaan yang lebih tinggi cenderung lebih mendapat kepuasan kerja. Mereka biasanya memperoleh kompensasi lebih baik, kondisi kerja lebih nyaman, dan pekerjaanpekerjaan mereka memungkinkan penggunaan segala kemampuan yang mereka punyai, sehingga mereka mempunyai alasan-alasan untuk lebih terpuaskan.

e.Ukuran organisasi

Ukuran organisasi perusahaan cenderung mempunyai hubungan secara berlawanan dengan kepuasan kerja. Semakin besar organisasi, kepuasan kerja cenderung turun secara moderat kecuali manajemen mengambil tindakan korektip. Tanpa tindakan koreksi, organisasi besar akan menjauhkan karyawannya dalam berbagai proses seperti partisipasi, komunikasi, dan koordinasi kurang lancar.

\section{METODE ANALISIS DATA}

Metode analisis data yang digunakan dalam penelitan ini adalah:

\section{Uji Validitas}

Uji validitas digunakan untuk menguji pertanyaan maupun pernyataan pada kuesioner yang disebar apakah pertanyaan maupun pernyataan tersebut valid atau tidak.Pengambilan keputusan dilakukan dengan cara membandingkan nilai r-hitung dengan r-tabel dengan taraf signifikan (kesalahan) 5\%. Dimana $r$ tabel diperoleh sebesar0,225 untuk df $=76-2=74 ; \alpha=0,05$. Bila rhitung lebih besar dari r-tabel maka butir pernyataan tersebut dikatakan valid. Untuk mengetahui valid atau tidaknya data yang diperoleh dari penelitian tersebut maka dapat dilakukan uji validitas.

\section{Uji Realibilitas}

Uji reliabilitas dilakukan terhadap item pernyataan yang dinyatakan valid. Suatu variabel dikatakan reliable atau handal jika jawaban terhadap pernyataan selalu konsisten

\section{Stastistik Deskriptif}

Statistik deskriptif adalah statistik yang digunakan untuk menganalisis data dengan cara menjelaskan gambaran data yang telah terkumpul sebagaimana adanya atau aslinya tanpa bermaksud untuk membuat kesipulan yang berlaku secara umum (Sugiyono 2015: 147).

\section{Uji Koefisien Korelasi}

Menurut Sugiyono (2013: 241) rumus koefisien korelasi Pearson Product Moment adalah sebagai berikut: 
$r_{x y}$

$=\frac{n\left(\sum X Y\right)-\left(\sum X\right) \cdot\left(\sum Y\right)}{\sqrt{\left\{n\left(\sum X^{2}\right)-\left(\sum X\right)^{2}\right\} \cdot\left\{n\left(\sum Y^{2}\right)-\left(\sum Y\right)^{2}\right\}}}$

$r_{x y}=$ Korelasi antara variabel $\mathrm{x}$ dan $\mathrm{y}$

$X=$ Jumlah skor variabel $\mathrm{x}$

$Y=$ Jumlah skor variabel y

$\mathrm{X}^{2}=$ Jumlah kuadrat seluruh skor $\mathrm{x}$

$\mathrm{Y}^{2}=$ Jumlah kuadrat seluruh skor $\mathrm{y}$

$N=$ Jumlah Sampel

Dengan demikian dapat dijelaskan ketentuan pengaruh yang terjadi adalah sebagai berikut:

a. Apabila nilai $r=0$

Artinya hubungan antara variabel $\mathrm{X}$ (bebas) dan variabel Y (terikat) tidak terdapat hubungan sama sekali. Jadi variabel X (bebas) tidak memberikan pengaruh terhadap peningkatan variabel Y (terikat).

b. Apabila nilai $r>0$

Artinya hubungan antara variabel $\mathrm{X}$ (bebas) dan variabel Y (terikat) atau sebaliknya merupakan hubungan yang positif. Semakin kecil nilai variabel $\mathrm{X}$ (bebas) maka akan semakin kecil pula nilai variabel $\mathrm{Y}$ (terikat).

c. Apabila nilai $r<0$

Artinya hubungan antara variabel $\mathrm{X}$ (bebas) dan variabel Y (terikat) merupakan hubungan yang negatif. Yaitu semakin kecil nilai variabel $\mathrm{X}$ (bebas) maka akan semakin besar nilai variabel $\mathrm{Y}$ (terikat) dan sebaliknya.

d. Apabila nilai $r=1$

Artinya tidak terdapat hubungan negatif yang sempurna antara variabel X (bebas) dan Y (terikat). e. Apabila nilai $r=-1$

Artinya terdapat hubungan negatif yang sempurna antara vaiabel $X$ (bebas) dan Y (terikat).

\section{Uji Regresi Linier Sederhana}

Analisis dapat dilanjutkan dengan menghitung persamaan regresinya. Analisis regresi linier sederhana adalah hubungan secara linear antara satu variabel bebas (X) dengan variabel terikat (Y). Menurut Sugiyono (2013: 247) persamaan regresi dapat digunakan untuk melakukan prediksi seberapa tinggi nilai variabel dependen bila nilai variabel independen dimanipulasi. Analisis ini untuk mengetahui arah hubungan antara variabel bebas dengan variabel terikat apakah positif atau negati dan untuk memprediksi nilai dari variabel terikat apabila nilai variabel bebas mengalami kenaikan atau penurunan. Data yang digunakan biasanya berskala interval atau rasio.

\section{Uji Koefisien Determinasi}

Setelah mengetahui nilai koefisien korelasi $\left(\mathrm{r}_{x y}\right)$ antara variabel (X) dan variabel (Y), selanjutnya dilakukan analisis koefisien determinasi. Tujuan analisis koefisien determinasi adalah untuk mengetahui seberapa besar hubungan antara variabel bebas (X) dan variabel (Y) dalam bentuk persentase $(\%)$. Dalam penelitian ini berarti analisis koefisien determinasi dilakukan untuk mengetahui pengaruh antara variabel lingkungan kerja dengan variabel kepuasan kerja dalam bentuk persentase (\%). Rumus yang digunakan dalam koefisien determinasi yaitu:

$$
\mathrm{KD}=r^{2} \times 100 \%
$$

Keterangan:

$$
\begin{aligned}
\mathrm{KD} & =\text { Koefesien determinasi } \\
r & =\text { Koefisien korelasi antara } X \\
& \text { dan } Y
\end{aligned}
$$


Besar kecilnya nilai koefisien determinasi ini menunjukkan besar kecilnya kontribusi variabel bebas (X) terhadap variabel $(\mathrm{Y})$.

\section{Uji Signifikasi Koefisien Korelasi}

Untuk dapat mengetahui pengaruh yang signifikan antara variabel (X) dan variabel (Y) maka perlu dilakukan uji signifikasi korelasi dengan menggunakan uji-t dengan rumus:

Keterangan:

$$
t=\frac{r \sqrt{n-2}}{\sqrt{1-r^{2}}}
$$

$n=$ Jumlah sampel

$t \quad=t_{\text {hitung }}$ yang selanjutnya

dibandingkan dengan $t_{\text {tabel }}$

$r \quad=$ Koefisien korelasi

Tingkat signifikasi dengan kriteria sebagai berikut:

a.Jika $t_{\text {hitung }}>$ dari $t_{\text {tabel }}$ maka $H_{0}$

b.diterima dan $H_{a}$ ditolak.

c.Jika $t_{\text {hitung }}<$ dari $t_{\text {tabel }}$ maka $H_{0}$

d.ditolak dan $H_{a}$ diterima.

e.Pengujian Hipotesis:

a. Ho: $r=0$ (tidak terdapat hubungan

yang signifikan antara $\mathrm{X}$ dan $\mathrm{Y}$ ).

b. Ha: $r \neq 0$ (terdapat hubungan yang

signifikan antara $\mathrm{X}$ dan $\mathrm{Y}$ ).

Untuk menghitung daerah keputusan (DK) denga taraf signifikasi dengan tingkat kesalahan $(\propto)=5 \%$, yaitu:

$\mathrm{DK}=n-2$

Dengan $n$ adalah jumlah populasi.

\section{ANALISIS DAN PEMBAHASAN ANALISIS DESKRIPTIF}

Analisis deskriptif mengemukakan gambaran umum mengenai data, dimana kita dapat mengemukakan informasi riil mengenai data penelitian yang digunakan. Penelitian ini dilakukan pada Pusat Pendidikan dan Pelatihan (PUSDIKLAT) Perdagangan Depok dengan menggunakan variabel lingkungan kerja (X) dan kepuasan kerja (Y). Adapun hasil rekapitulasi jawaban responden berdasarkan kuesioner yang telah disebar sebelumnya per variabel adalah sebagai berikut :

a. Deskripsi Lingkungan Kerja (X) Pusat Pendidikan dan Pelatihan

\section{Perdagangan Depok}

Hasil jawaban dari 76 responden terhadap

lingkungan kerja yang terdiri dari 10 unsur pernyataan, jawaban tersebut kemudian akan diuji oleh peneliti dengan menggunakan jumlah persentase jawaban, semuanya itu tertuang dan dijelaskan pada tabel berikut ini.

\section{Distribusi Jawaban Responden Terhadap Variabel LingkunganKerja (X)}

\begin{tabular}{|c|l|c|c|c|c|c|}
\hline No. & \multicolumn{1}{|c|}{ Pernyataan } & SS & S & RG & TS & STS \\
\hline 1. & $\begin{array}{l}\text { Perlengkapan penerangan lampu dalam ruangan } \\
\text { sudah baik dan memadai. }\end{array}$ & $\mathbf{3 6}$ & $\mathbf{4 0}$ & $\mathbf{0}$ & $\mathbf{0}$ & $\mathbf{0}$ \\
\hline 2. & $\begin{array}{l}\text { Suhu di ruangan kerja sudah cukup baik untuk } \\
\text { menunjang aktivitas kerja. }\end{array}$ & $\mathbf{3 2}$ & $\mathbf{3 9}$ & $\mathbf{5}$ & $\mathbf{0}$ & $\mathbf{0}$ \\
\hline 3. & $\begin{array}{l}\text { Tidak ada suara yang mengganggu di dalam } \\
\text { ruangan yang dapat mengganggu aktivitas kerja. }\end{array}$ & $\mathbf{1 7}$ & $\mathbf{4 8}$ & $\mathbf{7}$ & $\mathbf{3}$ & $\mathbf{1}$ \\
\hline
\end{tabular}


Jumlah hasil pernyataan = $\mathrm{SS}+\mathrm{S}+\mathrm{RG}+\mathrm{TS}+\mathrm{STS}$ yaitu $=186+$ $498+55+20+1=760$ dan selanjutnya untuk mencari presentase tiap jawaban adalah hasil tiap pernyataan dikalikan $100 \%$ seperti yang ditunjukan dibawah ini :

Jawaban SS $=\frac{186}{760} \times 100 \%=$ $24,47 \%$

Jawaban $S=\frac{498}{760} \times 100 \%=$ $65,53 \%$

Jawaban RG $=\frac{55}{760} \times 100 \%=$ $7,24 \%$

Jawaban TS $=\frac{20}{760} \times 100 \%=$ $2,63 \%$

Jawaban STS $=\frac{1}{760} \times 100 \%=$ $0,13 \%$

Dari hasil perhitungan diatas, hasil total jawaban yang menjawab sangat setuju (SS) sebesar 186 atau $24,47 \%$, yang menjawab setuju (S) sebesar 498 atau 65,53\%, yang menjawab ragu (RG) sebesar 55 atau $7,24 \%$, yang menjawab tidak setuju menjawab sangat tidak setuju (STS) sebesar 1 atau $0,13 \%$, dengan jumlah keseluruhan sebesar

760 atau 100\%.Dengan hasil kuesioner yang didapat, dapat disimpulkan bahwa lingkungan kerja sudah sangat baik yakni 90\%. Hal tersebut tercermin dari jawaban responden yang Sangat Setuju dan Setuju $(\mathrm{SS}+\mathrm{S})=(24,47 \%+65,53 \%)=$ 90\%. Tetapi masih ada kekurangan pada lingkungan kerja pada Pusdiklat Perdagangan.

\section{a.Deskripsi Kepuasan Kerja (Y) Pusat Pendidikan dan Pelatihan (PUSDIKLAT) Perdagangan Depok.}

Hasil jawaban dari 76 responden terhadap lingkungan kerja yang terdiri dari 10 unsur pernyataan, jawaban tersebut kemudian akan diuji oleh peneliti dengan menggunakan jumlah persentase jawaban, semuanya itu tertuang dan dijelaskan pada tabel berikut ini.

(TS) sebesar 20 atau 2,63\%, yang

\section{Distribusi Jawaban Responden Terhadap Variabel Kepuasan Kerja (Y)}

\begin{tabular}{|c|l|c|c|c|c|c|}
\hline No. & \multicolumn{1}{|c|}{ Pernyataan } & SS & S & RG & TS & STS \\
\hline 1. & $\begin{array}{l}\text { Saya tidak pernah berpikir untuk keluar } \\
\text { dari tempat kerja saya. }\end{array}$ & $\mathbf{0}$ & $\mathbf{4 5}$ & $\mathbf{5}$ & $\mathbf{2 6}$ & $\mathbf{0}$ \\
\hline 2. & $\begin{array}{l}\text { Saya tidak merasa jenuh dengan } \\
\text { pekerjaan saya. }\end{array}$ & $\mathbf{0}$ & $\mathbf{4 9}$ & $\mathbf{9}$ & $\mathbf{1 8}$ & $\mathbf{0}$ \\
\hline 3. & $\begin{array}{l}\text { Akan sangat berat bagi saya untuk } \\
\text { meninggalkan instansi ini sekarang, } \\
\text { sekalipun saya menginginkannya. }\end{array}$ & $\mathbf{1}$ & $\mathbf{3 1}$ & $\mathbf{3 4}$ & $\mathbf{1 0}$ & $\mathbf{0}$ \\
\hline 4. & $\begin{array}{l}\text { Saya mungkin akan keluar dari instansi } \\
\text { ini apabila ada kesempatan yang lebih } \\
\text { baik. }\end{array}$ & $\mathbf{0}$ & $\mathbf{4 7}$ & $\mathbf{2 3}$ & $\mathbf{6}$ & $\mathbf{0}$ \\
\hline 5. & Tingkat kehadiran saya cukup tinggi. & $\mathbf{2 1}$ & $\mathbf{4 2}$ & $\mathbf{9}$ & $\mathbf{4}$ & $\mathbf{0}$ \\
\hline 6. & $\begin{array}{l}\text { Di tempat kerja saya bekerja, } \\
\text { didominasi oleh kelompok usia muda. }\end{array}$ & $\mathbf{1}$ & $\mathbf{4 5}$ & $\mathbf{1 6}$ & $\mathbf{1 3}$ & $\mathbf{1}$ \\
\hline 7. & $\begin{array}{l}\text { Semua pegawai diberikan kesempatan } \\
\text { untuk promosi jabatan. }\end{array}$ & $\mathbf{2}$ & $\mathbf{4 3}$ & $\mathbf{1 9}$ & $\mathbf{1 2}$ & $\mathbf{0}$ \\
\hline
\end{tabular}




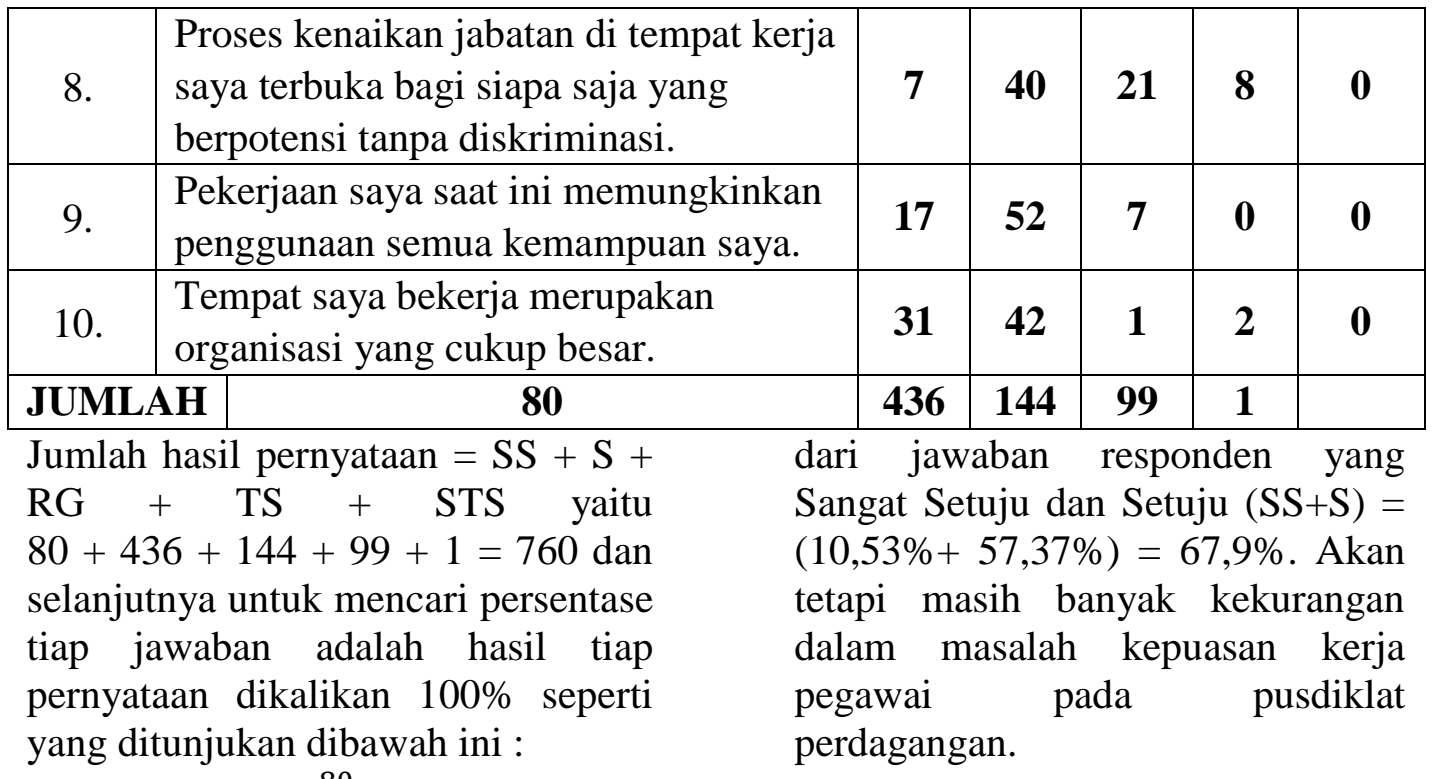

Jawaban SS $=\frac{80}{760} \times 100 \%=$

$10,53 \%$

Jawaban $S=\frac{436}{760} \times 100 \%=$ $57,37 \%$

Jawaban RG $=\frac{144}{760} \times 100 \%=$ $18,94 \%$

Jawaban TS $=\frac{99}{760} \times 100 \%=$ $13,03 \%$

Jawaban STS $=\frac{1}{760} \times 100 \%=$ $0,13 \%$

Dari hasil perhitungan diatas, hasil total jawaban yang menjawab sangat setuju (SS) sebesar 80 atau $10,53 \%$, yang menjawab setuju (S) sebesar 436 atau 57,37\%, yang menjawab ragu (RG) sebesar 144 atau $18,94 \%$, yang menjawab tidak setuju (TS) sebesar 99 atau 13,03\%, yang menjawab sangat tidak setuju (STS) sebesar 1 atau 0,13\%, dengan jumlah keseluruhan sebesar 760 atau $100 \%$.

Dengan hasil kuesioner yang didapat, dapat disimpulkan bahwa kepuasan kerja sudah lumayan baik yakni $67,9 \%$. Hal tersebut tercermin

\section{UJI VALIDITAS}

Uji validitas digunakan untuk menguji pertanyaan maupun pernyataan pada kuesioner yang disebar apakah pertanyaan maupun pernyataan tersebut valid atau tidak. Pengambilan keputusan dilakukan dengan cara membandingkan nilai r-hitung dengan r-tabel dengan taraf signifikan (kesalahan) 5\%. Dimana r-tabel diperoleh sebesar 0,225 untuk

df $=76-2=74 ; \alpha=0,05$. Bila $r-$ hitung lebih besar dari r-tabel maka butir pernyataan tersebut dikatakan valid. Untuk mengetahui valid atau tidaknya data yang diperoleh dari penelitian tersebut maka dapat dilakukan uji validitas.

\section{Hasil Perhitungan Validitas Butir Lingkungan Kerja (X)}

\begin{tabular}{|c|c|c|c|}
\hline No. & $\begin{array}{c}\mathbf{r} \\
\text { hitung }\end{array}$ & $\mathbf{r}$ tabel & Kesimpulan \\
\hline $\mathbf{1}$ & 0,533 & 0,225 & Valid \\
\hline $\mathbf{2}$ & 0,583 & 0,225 & Valid \\
\hline
\end{tabular}




\begin{tabular}{|c|c|c|c|}
$\mathbf{3}$ & 0,484 & 0,225 & Valid \\
\hline $\mathbf{4}$ & 0,705 & 0,225 & Valid \\
\hline $\mathbf{5}$ & 0,478 & 0,225 & Valid \\
\hline $\mathbf{6}$ & 0,403 & 0,225 & Valid \\
\hline $\mathbf{7}$ & 0,506 & 0,225 & Valid \\
\hline $\mathbf{8}$ & 0,264 & 0,225 & Valid \\
\hline $\mathbf{9}$ & 0,491 & 0,225 & Valid \\
\hline $\mathbf{1 0}$ & 0,336 & 0,225 & Valid \\
\hline
\end{tabular}

Sumber : Data Diolah 2017

Selanjutnya dilakukan uji-t, sebagai berikut:

$$
\begin{aligned}
\text { thitung } & =\frac{r \sqrt{n-2}}{\sqrt{1-r^{2}}} \\
& =\frac{0,533 \sqrt{76-2}}{\sqrt{1-0,533^{2}}} \\
& =\frac{0,533 \sqrt{74}}{\sqrt{1-} 0,284} \\
& =\frac{(0,533)(8,602)}{\sqrt{0,716}} \\
& =\frac{4,585}{0,846}=5,418
\end{aligned}
$$

Dengan demikian karena $t$ hitung lebih besar dari pada $t$ tabel $(5,418>1,992)$ hal tesebut menunjukkan bahwa terdapat pengaruh yang signifikan antara Lingkungan Kerja Terhadap Kepuasan Kerja Pegawai pada PUSDIKLAT Perdagangan.Adapun rekapitulasi hasil perhitungan butir pernyataan selanjutnya adalah sebagai berikut:

\section{Hasil Perhitungan Uji-t Butir} Lingkungan Kerja (X)

\begin{tabular}{|c|c|c|c|}
\hline No. & $\begin{array}{c}\mathbf{t} \\
\text { hitung }\end{array}$ & $\mathbf{t}$ tabel & Kesimpulan \\
\hline $\mathbf{1}$ & 5,418 & 1,992 & Valid \\
\hline $\mathbf{2}$ & 6,108 & 1,992 & Valid \\
\hline
\end{tabular}

\begin{tabular}{|c|c|c|c|}
$\mathbf{3}$ & 4,757 & 1,992 & Valid \\
\hline $\mathbf{4}$ & 8,552 & 1,992 & Valid \\
\hline $\mathbf{5}$ & 4,683 & 1,992 & Valid \\
\hline $\mathbf{6}$ & 3,788 & 1,992 & Valid \\
\hline $\mathbf{7}$ & 5,049 & 1,992 & Valid \\
\hline $\mathbf{8}$ & 2,86 & 1,992 & Valid \\
\hline $\mathbf{9}$ & 4,848 & 1,992 & Valid \\
\hline $\mathbf{1 0}$ & 3,068 & 1,992 & Valid \\
\hline
\end{tabular}

a. Uji Validitas Variabel Kepuasan Kerja(Y)

\section{Hasil Perhitungan Validitas Butir} Kepuasan Kerja (Y)

\begin{tabular}{|c|c|c|c|}
\hline No. & $\begin{array}{c}\mathbf{r} \\
\text { hitung }\end{array}$ & $\mathbf{r}$ tabel & Kesimpulan \\
\hline $\mathbf{1}$ & 0,342 & 0,225 & Valid \\
\hline $\mathbf{2}$ & 0,339 & 0,225 & Valid \\
\hline $\mathbf{3}$ & 0,400 & 0,225 & Valid \\
\hline $\mathbf{4}$ & 0,360 & 0,225 & Valid \\
\hline $\mathbf{5}$ & 0,363 & 0,225 & Valid \\
\hline $\mathbf{6}$ & 0,478 & 0,225 & Valid \\
\hline $\mathbf{7}$ & 0,565 & 0,225 & Valid \\
\hline $\mathbf{8}$ & 0,589 & 0,225 & Valid \\
\hline $\mathbf{9}$ & 0,471 & 0,225 & Valid \\
\hline $\mathbf{1 0}$ & 0,458 & 0,225 & Valid \\
\hline
\end{tabular}

Selanjutnya dilakukan uji-t

$$
\begin{aligned}
\text { thitung } & =\frac{r \sqrt{n-2}}{\sqrt{1-r^{2}}} \\
& =\frac{0,342 \sqrt{76-2}}{\sqrt{1-0,342^{2}}}
\end{aligned}
$$




$$
\begin{aligned}
& =\frac{0,342 \sqrt{74}}{\sqrt{1-} 0,117} \\
& =\frac{(0.342)(8,602)}{\sqrt{0,883}} \\
& =\frac{2,942}{0,939} \\
& =3,133
\end{aligned}
$$

Dengan demikian karena $\mathrm{t}$ hitung lebih besar dari pada $\mathrm{t}$ tabel $(3,133>1,992)$ hal tersebut menunjukkan bahwa terdapat pengaruh yang signifikan antara Lingkungan Kerja Terhadap Kepuasan Kerja Pegawai pada PUSDIKLAT Perdagangan.Adapun rekapitulasi hasil perhitungan butir pernyataan selanjutnya adalah sebagai berikut:

\section{Hasil Perhitungan Uji-t Butir Kepuasan Kerja (Y)}

\begin{tabular}{|c|c|c|c|}
\hline No. & $\begin{array}{c}\mathrm{t} \\
\text { hitung }\end{array}$ & $\begin{array}{c}\mathrm{t} \\
\text { tabel }\end{array}$ & Kesimpulan \\
\hline $\mathbf{1}$ & 3,133 & 1,992 & Valid \\
\hline $\mathbf{2}$ & 3,099 & 1,992 & Valid \\
\hline $\mathbf{3}$ & 3,756 & 1,992 & Valid \\
\hline $\mathbf{4}$ & 3,319 & 1,992 & Valid \\
\hline $\mathbf{5}$ & 3,353 & 1,992 & Valid \\
\hline
\end{tabular}

\begin{tabular}{|c|c|c|c|}
\hline No. & $\begin{array}{c}\mathrm{t} \\
\text { hitung }\end{array}$ & $\begin{array}{c}\mathrm{t} \\
\text { tabel }\end{array}$ & Kesimpulan \\
\hline $\mathbf{6}$ & 4,379 & 1,992 & Valid \\
\hline $\mathbf{7}$ & 5,891 & 1,992 & Valid \\
\hline $\mathbf{8}$ & 6,269 & 1,992 & Valid \\
\hline $\mathbf{9}$ & 4,593 & 1,992 & Valid \\
\hline $\mathbf{1 0}$ & 4,431 & 1,992 & Valid \\
\hline
\end{tabular}

Sumber : Data Diolah 201

\section{UJI REALIBILITAS}

Uji reliabilitas dilakukan terhadap item pernyataan yang dinyatakan valid. Suatu variabel dikatakan reliable atau handal jika jawaban terhadap pernyataan selalu konsisten.

\section{a. Uji Realibilitas Variabel}

\section{Lingkungan Kerja (X)}

1) Menghitung varians skor setiap butir pernyataan dengan rumus

$$
S i=\frac{\sum X i^{2}-\frac{\sum X i^{2}}{n}}{n}
$$

Contoh Perhitungan Varians Butiran Pernyataan No. 1

Diketahui:

$$
\begin{aligned}
& \Sigma x \mathrm{i}=340 \\
& \Sigma \mathrm{xi}^{2}=1540 \\
& n=76
\end{aligned}
$$

$$
\begin{gathered}
S i=\frac{\sum X i^{2}-\frac{\sum X i^{2}}{n}}{n}=\frac{1540-\frac{340^{2}}{76}}{76} \\
=\frac{1540-\frac{115600}{76}}{76} \\
=\frac{1540-1521,05}{76} \\
=\frac{18,95}{76} \\
=0,249
\end{gathered}
$$

Varians butir ke -2 sampai ke -10 dapat dihitung dengan cara yang sama seperti mengjitung butir 1 .

2) Menghitung jumlah varians skor butir pernyataan

$\Sigma S i^{2}=S i^{2} 1+S i^{2} 2+S i^{2} 3+\ldots .+$ $S i^{2} n$

$\Sigma S i^{2}=0,249+0,360+0,592+0,523$ $+0,425+0,489+0,600+0,331+$ $0,308+0,338=4,215$

3) Menghitung varians total

Diketahui :

$\Sigma X \mathrm{t}=3128$

$\Sigma X t^{2}=129440$ 


$$
\begin{gathered}
S t=\frac{\sum X t^{2}-\frac{\sum X t^{2}}{n}}{n} \\
=\frac{129440-\frac{3128^{2}}{76}}{76} \\
=\frac{129440-\frac{9784384}{76}}{76} \frac{129440-128741,89}{76} \\
=\frac{698,11^{76}}{76} \\
=9,185
\end{gathered}
$$

4) Menghitung reabilitas variabel

$$
\begin{aligned}
& r c a=\left(\frac{k}{k-1}\right)\left(1-\frac{\sum S i^{2}}{\sum S t^{2}}\right) \\
&=\left(\frac{10}{10-1}\right)(1 \\
&\left.-\frac{4,215}{9,185}\right) \\
&=(1,111)(1-0,449)
\end{aligned}
$$

Dengan demikian karean hasil perhitungan $r_{c a}$ lebih besar dari $r_{\text {tabel }}(0.601>0,225)$ sehingga instrument penelitian Lingkungan Kerja dapat dikatakan reliable.

\section{b.Uji Realibilitas Variabel} Kepuasan Kerja (Y)

1) Menghitung varians skor setiap butir pernyataan dengan rumus :

$$
S i=\frac{\sum X i^{2}-\frac{\sum X i^{2}}{n}}{n}
$$

Contoh Perhitungan Varians Butiran Pernyataan No. 1

Diketahui:

$$
\begin{aligned}
& \begin{aligned}
& \Sigma \mathrm{xi}=247 \\
& \Sigma \mathrm{xi}^{2}=869 \\
& n=76
\end{aligned} \\
& \text { Si }=\frac{\sum X i^{2}-\frac{\sum X i^{2}}{n}}{n} \\
& =\frac{869-\frac{247^{2}}{76}}{76} \\
& =\frac{869-\frac{61009}{76}}{76}
\end{aligned}
$$

$$
\begin{aligned}
& =\frac{869-802,75}{76} \\
& =\frac{66,25}{76}=0,871
\end{aligned}
$$

Varians butir ke -2 sampai ke -10 dapat dihitung dengan cara yang sama seperti mengjitung butir 1 .

2) Menghitung jumlah varians skor butir pernyataan

$\Sigma S i^{2}=S i^{2} 1+S i^{2} 2+S i^{2} 3+\ldots$. $+S i^{2} n$

$$
\Sigma S i^{2}=0,871+0,715+0,500
$$

$+0,406+0,602+0,691+0,616+$ $0,633+0,298+0,409=5,741$

3) Menghitung varians total Diketahui :

$$
\begin{aligned}
& \Sigma X \mathrm{t}=2775 \\
& \Sigma X t^{2}=102133
\end{aligned}
$$

$$
\begin{array}{r}
=(1,111)(0,541) \quad=\frac{\sum \neq 0,60 \frac{\sum X t^{2}}{n}}{n} \backslash \\
=\backslash \\
=\frac{102133-7700625}{76} \\
=\frac{102133-101324,01}{76} \\
=\frac{808,99}{76}
\end{array}
$$

$$
=10,645
$$

4) Menghitung reabilitas variabel

$$
\begin{gathered}
r c a=\left(\frac{k}{k-1}\right)\left(1-\frac{\sum S i^{2}}{\sum S t^{2}}\right) \\
=\left(\frac{10}{10-1}\right)\left(1=\frac{5,741}{10,645}\right) \\
=(1,111)(1-0,539) \\
=(1,111)(0,461) \\
=0,512
\end{gathered}
$$

Dengan demikian karean hasil perhitungan $r_{c a}$ lebih besar dari $r_{\text {tabel }}(0.512>\quad 0,225) \quad$ sehingga instrument penelitian Lingkungan Kerja dapat dikatakan reliable.

Hasil Rangkuman Uji Reliabilitas

\begin{tabular}{|l|l|c|c|}
\hline Variabel & Rca & $\begin{array}{c}\mathrm{r}- \\
\text { tabe }\end{array}$ & $\begin{array}{c}\text { Keterang } \\
\text { an }\end{array}$ \\
\hline
\end{tabular}




\begin{tabular}{|l|c|c|l|}
\hline & & 1 & \\
\hline $\begin{array}{l}\text { Lingkung } \\
\text { an Kerja } \\
(X)\end{array}$ & $\begin{array}{c}0,60 \\
1\end{array}$ & $\begin{array}{c}0,22 \\
5\end{array}$ & Reliabel \\
\hline $\begin{array}{l}\text { Kepuasan } \\
\text { Kerja (Y) }\end{array}$ & $\begin{array}{c}0,51 \\
2\end{array}$ & $\begin{array}{c}0,22 \\
5\end{array}$ & Reliabel \\
\hline
\end{tabular}

Sumber : Data Diolah 2017

Dari data di atas dapat dilihat bahwa dari hasil perhitungan reliabilitas rca (Realibiltas Croncbath Alpha) Variabel Lingkungan Kerja dan Kepuasan Kerja lebih besar dari r-tabel sehingga instrumen penelitian Lingkungan Kerja dan Kepuasan Kerja dapat dikatakan reliable (dipercaya).

\section{Analisis Koefisien Korelas}

Analisis korelasi merupakan istilah yang digunakan untuk mengukur kekuatan hubungan antara variabel.

Berdasarkan analisis diatas dengan menggunakan korelasi pearson product moment didapat nilai $r_{x y}$ sebesar 0,678 dan sesuai dengan pedoman interprestasi koefisien korelasi maka dapat dikatakan bahwa nilai korelasi antara Lingkungan Kerja terhadap Kepuasan Kerja sebesar 0,678 yang artinya terdapat pengaruh positif yang kuat antar Lingkungan Kerja terhadap Kepuasan Kerja PegawaiPUSDIKLAT Perdagangan Depok.

\section{Uji Regresi Linier Sederhana}

Analisisregresi linier sederhana digunakan untuk melihat ada tidaknya pengaruh lingkungan kerja terhadap kepuasan kerja pegawai.
Dengan menggunakan analisis ini dapat diketahui berapa besar perubahan yang terjadi pada kepuasan kerja pegawai jika terjadi perubahan lingkungan kerja. Berikut perhitungan Uji Regresi Linier Sederhana :

Diketahui:

$$
\begin{array}{ll}
\mathrm{n} & =76 \\
\Sigma \mathrm{X} & =3128 \\
\Sigma \mathrm{Y} & =2775 \\
\Sigma X^{2} & =129440 \\
\Sigma Y^{2} & =102133 \\
\Sigma \mathrm{XY} & =114723 \\
\mathrm{a}=\frac{\left(\sum Y\right)\left(\sum X^{2}\right)-\left(\sum X\right)\left(\sum X Y\right)}{n\left(\sum X^{2}\right)-\left(\sum X\right)^{2}} \\
= \\
\frac{(2775)(129440)-(3128)(114723)}{76(129440)-(3128)^{2}} \\
=\frac{359196000-358853544}{9837440-9784384} \\
=\frac{342456}{53056} \\
=6,454
\end{array}
$$

Selanjutnya menghitung nilai $\mathrm{b}$ :

$$
\begin{gathered}
b=\frac{n\left(\sum X Y\right)-\left(\sum X\right)\left(\sum Y\right)}{n\left(\sum X^{2}\right)-\left(\sum X\right)^{2}} \\
=\frac{76(114723)-(3128)(2775)}{76(129440)-(3128)^{2}} \\
=\frac{8718948-8680200}{9837440-9784384} \\
=\frac{38748}{53056} \\
=0,730
\end{gathered}
$$

Persamaan regresi Linier :

$$
\begin{aligned}
Y & =a+b(x) \\
& =6,454+0,730 x
\end{aligned}
$$

Berdasarkan hasil perhitungan analisis koefisien regresi tersebut diatas menunjukan hasil (a) adalah 6,454 dan (b) adalah 0,730 Dapat diperoleh persamaan model regresi $\mathrm{Y}=\mathrm{a}+\mathrm{b}(\mathrm{x})$ atau 
$6,454+0,730$ x. arti dari perhitungan diatas yaitu :

a. Konstanta atau $\mathrm{a}=6,454$ memiliki arti jika lingkungan kerja tidak ada, maka kepuasan kerja masih ada sebesar 0,730.

b.Koefisien regresi atau $\mathrm{b}=0,730$ menunjukan arah yang positif artinya kenaikan lingkungan kerja (X) sebesar satuan. Maka kepuasan kerja akan meningkat sebesar $\quad 0,730 \% \quad$ dengan asumsilingkungan kerja (X) dianggap konstan.

\section{Uji Koefisien Determinasi}

$\begin{array}{cc}\text { Koefisien } & \text { determinasi } \\ \text { digunakan untuk mengetahui }\end{array}$ seberapa besar hubungan antara variabel bebas $(\mathrm{X})$ dan variabel $(\mathrm{Y})$ dalam bentuk persentase (\%). Dalam penelitian ini berarti analisis koefisien determinasi dilakukan untuk mengetahui pengaruh antara variabel lingkungan kerja dengan variabel kepuasan kerja dalam bentuk persentase (\%). Perhitungan koefisien determinasi adalah sebagai berikut :

$$
\begin{aligned}
K D= & \mathrm{r}_{\mathrm{xy}}{ }^{2} \times 100 \% \\
& =(0,678)^{2} \times 100 \% \\
& =0,459 \times 100 \% \\
& =45,96 \%
\end{aligned}
$$

Dari perhitungan koefisien determinasi diperoleh nilai $45,96 \%$. Hal ini menunjukan bahwa pengaruh lingkungan kerja terhadap kepuasan kerja pada PUSDIKLAT Perdagangan Depok yakni sebesar $45,96 \%$, sedangkan sisanya $(100 \%$ $45,96 \%)=54,04 \%$ kepuasan kerja PUSDIKLAT Perdagangan dipengaruhi oleh variabel lainnya yang tidak diteliti oleh penulis.

\section{Uji Hipotesis (Uji-t)}

Uji hipotesis diperlukan untuk menguji apakah lingkungan kerja berpengaruh terhadap kepuasan kerja. Menurut sugiyono (2015:64) hipotesis merupakan jawaban sementara terhadap rumusan masalah penelitian, oleh karena itu rumusan masalah penelitian biasanya disusun dalam bentuk kalimat pertanyaan. Dengan demikian hipotesis penelitian dapat diartikan sebagai jawaban yang bersifat sementara terhadapmasalah peneltian, sampai terbukti mealalui data yang terkumpul dan harus diuji secara empiris. Berikut adalah hipotesis yang digunakan dalam penelitian ini

Ho: Tidak terdapat pengaruh lingkungan kerja terhadap kepuasankerjapegawai pada PUSDIKLAT Perdagangan Depok.

Ha : Terdapat pengaruh lingkungan kerja terhadap kepuasan kerja pegawai pada PUSDIKLAT Perdagangan Depok.

Dan berikut adalah perhitungan uji hipotesis :

$$
\begin{aligned}
& \mathrm{t}_{\text {hitung }}=\frac{r x y \sqrt{n-2}}{\sqrt{1-r x y^{2}}} \\
& =\frac{0,678 \sqrt{76-2}}{\sqrt{1-0,678^{2}}} \\
& =\frac{0,678 \sqrt{74}}{\sqrt{1-0,459}} \\
& =\frac{5,832}{\sqrt{0,541}} \\
& =\frac{5,832}{0,735} \\
& =7,934
\end{aligned}
$$

Karena $t_{\text {hitunglebih besar dari pada }}$ $t_{\text {tabel }}(7,934>1,992)$, hal tersebut menunjukan bahwa terdapat pengaruh yang signifikan antara lingkungan kerja terhadap kepuasan 
kerja pada PUSDIKLAT Perdagangan depok

\section{KESIMPULAN, DAN SARAN KESIMPULAN}

Berdasarkan uraian-uraian yang telah dikemukakan pada bab-bab sebelumnya, akhirnya penulis sampai pada bagian akhir dari skripsi ini, yaitu penulis mencoba memberikan beberapa kesimpulan. Adapun kesimpulan yang diperoleh dari penelitian skripsi ini adalah sebagai berikut:

1. Lingkungan Kerja pada Pusat Pendidikan dan Pelatihan (PUSDIKLAT) Perdagangan Depok tergolong baik, hal ini tercermin dari jawaban responden Sangat Setuju 186 atau (24,47\%), Setuju 498 atau (65,53\%), Ragu-ragu 55 atau (7,24\%), Tidak Setuju 20 atau $(2,63 \%)$, dan Sangat Tidak 1 atau $(0,13 \%)$.

2. Kepuasan Kerja Pegawai pada Pusat Pendidikan dan Pelatihan (PUSDIKLAT) Perdagangan Depok tergolong lumayan baik, hal ini tercermin dari jawaban responden Sangat Setuju 80 atau (10,53\%), Setuju 436 atau $(57,37 \%)$, RaguRagu 144 atau $(18,94 \%)$, Tidak Setuju 99 atau (13,03\%), dan Sangat Tidak Setuju 1 atau $(0,13 \%)$.

3. Pengaruh Lingkungan Kerja Terhadap Kepuasan Kerja Pegawai pada Pusat Pendidikan dan Pelatihan (PUSDIKLAT) Perdagangan Depok, dari analisis data yang peneliti lakukan menyimpulkan bahwa persamaan regresi $\mathrm{Y}=\mathrm{a}+\mathrm{bx}$ yang telah ditemukan adalah $6,454+0,730 \mathrm{x}$ persamaan regresi yang telah ditemukan tersebut dapat diartikan jika lingkungan kerja diterapkan dengan baik maka akan meningkatkan kepuasan kerja pegawai, begitu pula sebaliknya. Koefisien regresi $X=0,730$ akan bertambah 1 satuan dengan asumsi konstanta 6,454 satuan. Sedangkan dari hasil analisis perhitungan menggunakan rumus koefisien korelasi product moment yaitu sebesar $\mathrm{r}=0,768$ yang termasuk kategori $\operatorname{KUAT}(0,60-0,799)$. Sedangkan nilai koefisien determinasi yang diperoleh sebesar $45,96 \%$ menunjukan bahwa kepuasan kerja dipengaruhi oleh lingkungan kerja sebesar 45,96\%, sedangkan sisanya $54,04 \%$ dipengaruhi beberapa faktor atau variabel lain yang tidak diteliti dalam penelitian ini. Dan hasil pengujian hipotesis atau uji signifikan diperoleh nilai bahwa thitung lebih besar dari pada t-tabel $(7,934>1,992)$ maka Ha diterima dan Ho ditolak, artinya Terdapat Pengaruh Lingkungan Kerja Terhadap Kepuasan Kerja pada Pusat Pendidikan dan Pelatihan (PUSDIKLAT) Perdagangan Depok.

\section{A. Saran}

Berdasarkan hasil penelitian yang telah dilakukan, hasil analisis dari pembahasan yang telah diuraikan, maka penulis memberikan saran sebagai bahan pertimbangan sebagai berikut :

1. Pada variabel lingkungan kerja yang paling lemah adalah pernyataan nomor 7 pada indikator dekorasi di tempat kerja yaitu Ruangan kerja saya terdekorasi dengan rapih. Yakni dengan jawaban Tidak Setuju sebanyak 8 atau 10,52\%. Maka 
untuk lebih baik lagi, instansi harus lebih memperhatikan dekorasi ruangan kerja pegawainya agar tetap rapih serta melibatkan para pegawainya untuk ikut serta dalam menata ruangan kerja mereka supaya tercipta ruangan yang nyaman bagi para pegawai.

2. Pada variabel kepuasan kerja pegawai yang paling lemah adalah pernyataan nomor 1 pada indikator tingkat perputaran karyawan yaitu saya tidak pernah berfikir untuk keluar dari tempat kerja saya. Yakni dengan jawaban Tidak Setuju sebanyak 26 atau 34,21\%. Maka untuk lebih baik lagi, sebaiknya instansi harus lebih memperhatikan keinginan dari para pegawai serta menciptakan suasana dan lingkungan pekerjaan yang nyaman supaya para pegawai bersikap loyal terhadap instansi.

3. Pengaruh lingkungan kerja terhadap kepuasan kerja pegawai sebesar $45,96 \%$, sedangkan sisanya $54,04 \%$ dipengaruhi oleh faktor lain, hal ini menunjukkan bahwa kondisi masing-masing variabel harus ditingkatkan secara signifikan, oleh karena itu penlitimengajukan saran yang dapat dilakukan kepada peneliti selanjutnya dengan variabel independen yang berbeda, agar mendapat hasil yang akurat mengenai pengaruh variabel lain terhadap Kepuasan Kerja Pegawai pada Pusat Pendidikan dan Pelatihan (PUSDIKLAT) Perdagangan Depok.

\section{DAFTAR PUSTAKA}

Al Choir, Fikron., "Teori Dan Aplikasi Statistika Deskriptif Untuk Ekonomi DanBisnis",
CV. Asmoro Mediatama, Tangerang Selatan, 2014.

Arikunto., "Prosedur Penelitian: Suatu Pendekatan Praktek", Rineka Cipta,Jakarta, 2010.

Feriyanto., Andri., \& Endang., "Pengantar Manajemen (3 in 1)", Mediatara, Kebumen, 2015.

Handoko, T. Hani., "Manajemen Personalia \& Sumber Daya Manusia", BPFE, Yogyakarta, 2014.

Handoko, T. Hani., "Manajemen", Edisi Kedua, Cetakan 26, BPFE, Yogyakarta, 2014.

Idris, Henki., \& Wiryawan, Zahrida., "Pengantar Manajemen", In Media, Bogor , 2015.

Ishak., \& Tanjung, Hendri., "Manajemen Sumber Daya Manusia", Universitas Trisakti, Jakarta, 2003.

Mangkunegara., "Manajemen Sumber Daya Manusia Perusahaan", PT. Remaja Rosda Karya, Bandung, 2011.

Nitisemito, Alex S., "Manajemen Personalia", Ghalia Indonesia, Jakarta, 2001.

Nurjaman, Kadar., "Manajemen Personalia", CV. Pustaka Setia, Bandung, 2014.

Rivai, Veithzal., \& J. Sagala, Eva., "Manajemen Sumber Daya Manusia Untuk Perusahaan: Dari Teori Ke Praktik", PT. 
Rajagrafindo Persada, Jakarta, 2009.

Robbins, Stephen., "Perilaku Organisasi”, Salemba Empat, Jakarta, 2002.

S.P Hasibuan, Malayu., "Manajemen Sumber Daya Manusia", PT. Bumi Aksara, Jakarta, 2014.

Sedarmayanti., "Sumber Daya Manusia dan Produktivitas Kerja”, CV. Mandar Maju, Bandung, 2009.

Sedarmayanti., "Tata Kerja Dan Produktivitas Kerja", CV. Mandar Maju, Bandung, 2011.

Sofyandi, Herman., "Manajemen Sumber Daya Manusia", Graha Ilmu, Yogyakarta, 2008.

Sugiyono., "Metode Penelitian Kuantitatif, Kualitatif, Dan $R \& D$ ”, Alfabeta, Bandung, 2015.

Sugiyono.,"Statistika

Untuk

Penelitian",

Alfabeta,

Bandung, 2013.

Sunyoto, Danang., "Manajemen Sumber Daya Manusia", PT. Buku Seru, Jakarta, 2012.

Supardi., "Aplikasi Statistika Dalam Penelitian: Konsep Statistika Yang Lebih

Komprehensif",Change

Publication, Jakarta, 2013.

Suparno., "Manajemen pengebangan Sumber Daya Manusia", Pustaka Pelajar, Yogyakarta, 2015.
Syukur, Fatah., "Manajemen Sumber Daya anusia Pendidikan", PT. Pustaka Rizki Putra, Semarang, 2012.

Wibowo., "Manajemen Kinerja", Edisi Kelima, PT. Rajagrafindo Persada, Jakarta, 2016. 